\title{
Labour Force Participation and Tax-Benefit Systems: A Cross-Country Comparative Perspective
}

\author{
Kamil Galuščák and Gábor Kátay*
}

\begin{abstract}
This paper investigates the extent to which cross-country differences in aggregate participation rates can be explained by divergence in tax-benefit systems. We take the example of two countries, the Czech Republic and Hungary, which - despite a lot of similarities - differ markedly in labour force participation rates. We first replicate for Czech household-level data the labour supply estimation for Hungary presented in Benczúr et al. (2014) and use the two perfectly comparable estimates to simulate how the aggregate participation rate would change in one country if the other country's tax and social welfare system were adopted. Our estimation results yield similar labour supply elasticities for both countries, suggesting that individual preferences are essentially identical. The simulation results show that about one-half of the total difference in the participation rates of the 15-74 years old population can be explained by differences in the tax-benefit systems. The highest response is obtained for married women or women of childbearing age. This is related to the more generous maternity benefit system in place in Hungary as compared to the Czech Republic.
\end{abstract}

JEL Codes: $\quad$ C63, H24, I38, J22, P50.

Keywords: Cross-country comparison, labour supply, microsimulation, participation rate, tax-benefit systems.

\footnotetext{
* Kamil Galuščák, Czech National Bank, kamil.galuscak@cnb.cz.

Gábor Kátay, corresponding author, Banque de France, gabor.katay@banque-france.fr.
}

This research was supported by Czech National Bank Research Project No. D1/12. The views expressed in this paper are those of the authors and not necessarily those of the institutions the authors are affiliated with. We thank seminar participants at the Banque de France, the Czech National Bank and the Czech Economic Society Biennial Conference, and Martin Guzi, Tomáš Konečný and Daniel Münich for their valuable comments. 


\section{Introduction}

Cross-country comparison of labour force participation rates is the most straightforward way to identify labour supply problems in a particular country or set of countries. International organisations, central banks and economic think-tanks often motivate their policy recommendations by comparing a country's participation rate - usually broken down by selected sub-populations - against an international standard or against other similar countries' statistics. The resulting recommendations frequently involve - but are not limited to - reform of the country's tax and welfare system to restore or improve work incentives. ${ }^{1}$ That is, the financial incentive to work is implicitly the primary candidate for explaining cross-country differences in the participation rates of apparently homogeneous groups of individuals. Is this really the most important factor in explaining cross-country differences, or are other aspects such as differences in preferences or non-financial incentives even more important? To what extent can differences in financial incentives explain the observed differences between countries in labour force participation? Although the impact of labour taxation and the welfare benefit system on labour force participation has been widely investigated in the empirical literature, the extent to which cross-country differences in participation rates can be explained by the diversity of tax-benefit systems has never been addressed directly.

To fill the gap, we take the example of two countries, the Czech Republic and Hungary. We use, for both countries, a very detailed, complex microsimulation model and perfectly comparable micro estimates of labour supply at the extensive margin (i.e. the participation decision) to quantify the portion of the divergence in the two countries' participation rates explained by differences in their taxation and welfare benefit systems. More precisely, we first replicate for Czech individual-level data the labour supply estimation for Hungary presented in Benczúr et al. (2014). The two entirely comparable estimated equations for the Czech Republic and Hungary are then used to simulate how the aggregate participation rate would change in one country if it adopted the other country's tax and social welfare system.

To the best of our knowledge, this paper offers the first tentative explanation of cross-country differences in labour force participation rates by differences in taxation and welfare benefits. The closest strand of literature uses cross-country individual-level or disaggregated data either to investigate the labour supply effects of a specific policy change or to explain developments in participation rates from a cross-country comparative perspective. For the sake of completeness, some recent cross-country empirical studies analyse the effect of hypothetical welfare reforms (e.g. Immervoll et al., 2007); others study the effects of tax reforms (see e.g. Aaberge et al., 2000,

\footnotetext{
${ }^{1}$ For example, see OECD (2012), OECD (2014) and IMF (2013) for assessments of labour force participation in Hungary and the Czech Republic - the two countries this paper focuses on - and for resulting policy recommendations. By comparing labour force participation rates in OECD countries, OECD (2012) concludes that "... structural reforms are also needed (in Hungary) to better exploit existing resources and raise one of the lowest activity rates in the OECD”. Similarly, IMF (2013) urges Hungary to "... raise the exceptionally low labor participation rate". OECD (2014) welcomes the fact that Czech "labour force participation has increased to the European average", although the relatively low labour force participation of women is identified as a bottleneck for the Czech Republic as well. In order to catch up with countries with higher participation rates, IMF staff recommend that Hungary implement "a more employment-friendly taxation for low income earners" and "raise women's participation in the labor market by reorienting public spending from cash benefits [...] towards the development of high quality early childhood education and day care centers." Similarly, the OECD recommends that Hungary "preserve work incentives when lowering the tax wedge" to "promote the participation of the elderly" and to "reform family policies to enhance women's labour market participation".
} 
or Paulus and Peichl, 2008, for a cross-country analysis of flat-tax reforms); cross-country microsimulation models are also used to estimate governments' redistributive preferences (Blundell et al., 2009; Bargain et al., 2011). Some other papers use individual-level or disaggregated data to describe the evolution of labour supply in some selected countries, either for the whole population (Balleer et al., 2009, or Blundell et al., 2011) or for a selected subpopulation (e.g. Cipollone et al., 2013, for women). However, to the best of our knowledge, none of these papers or any other existing empirical ones have so far provided direct evidence to explain differences in participation rates between countries.

The Czech Republic and Hungary provide an interesting case for comparison. The two countries exhibit a lot of similarities: their economies are geographically close, are similar in size and level of economic development, and partly share a common history. In particular, both economies experienced full employment until the regime change at the end of the 1980s. Despite all their common factors, their participation rates differ markedly nowadays. In 2013, with only $57.5 \%$ of the 15-74 years old population working or actively seeking employment, Hungary recorded the fourth lowest participation rate among the EU member states (behind Croatia, Italy and Malta), while the Czech participation rate was close to the EU15 average (64.3\% in the Czech Republic and $64.8 \%$ in the EU15). ${ }^{2}$

These differences are typically explained by different labour market policies adopted during the first few years of the transition process and kept - at least partly - unchanged since then. Both countries implemented fast-track reforms in the early 1990s, with two main differences. First, Hungary opted for case-by-case privatisation as opposed to the voucher privatisation method adopted by the former Czechoslovakia. Second, the Hungarian government introduced a strict bankruptcy regulation in 1992.

After an initial collapse, the widespread changes to the economic system shifted both economies to a relatively fast growing path. Nevertheless, the differences in the privatisation methods and the draconian bankruptcy regulation implemented in Hungary provoked a much larger drop in employment in Hungary as compared to Czechoslovakia. Between 1990 and 1993, total employment declined by $9 \%$ in Czechoslovakia and by $22 \%$ in Hungary. Moreover, in Hungary, a number of policy measures - such as alleviated conditions for entering the old-age or disability pension systems - contributed to pushing people out of the labour force rather than into unemployment. As a result, the participation rate declined continuously until 1997, when it reached only $50.6 \%$ of the $15-74$ years old population, about 10 percentage points lower than the EU15 average and more than 13 percentage points lower than in the Czech Republic. ${ }^{3}$

As we will see, in 2008, the Hungarian transfer system could still be viewed as "generous" relative to the Czech system. After presenting our methodology (in the next section), we describe the key differences between the two countries' tax and social welfare systems (Section 3).

Our results (presented in Section 4) show, first, that the estimated labour supply elasticities for the Czech Republic are very close to the results for Hungary, suggesting that, at least in this dimension, individual preferences are similar in the two countries. This holds true even for subpopulations depending on the level of education, gender and marital status: in both countries,

\footnotetext{
${ }^{2}$ Eurostat data, September 2014.

${ }^{3}$ For a detailed analysis of the evolution of the Hungarian participation rate, see Kátay and Nobilis (2009).
} 
lower educated people, the elderly and married women (of childbearing age) are the most responsive to tax and transfer changes. Given the large dispersion of the labour supply elasticities found in the empirical literature for different countries and time periods, the similarities of the estimated elasticities for the two countries we analyse are in line with the evidence in Bargain et al. (2012) suggesting that a considerable part of the cross-country variation in the elasticities found in the literature is driven by methodological differences.

Second, the simulation results suggest that about one-half of the total difference in the participation rates of the 15-74 years old population can be explained by differences in the taxbenefit systems. The results are quasi-symmetric, meaning that if the Czech system was adopted, the Hungarian participation rate would increase by about the same number of percentage points that the Czech participation would decrease by if the Hungarian system were implemented. The highest responses are obtained for married women and women of childbearing age. This is related to the much more generous maternity benefit system in place in Hungary as compared to the Czech Republic.

\section{Methodology}

We first replicate the estimation in Benczúr et al. (2014) for Czech data and compare our results with the Hungarian estimates of labour supply at the extensive margin. By closely following the approach specified in Benczúr et al. (2014), we estimate a fully parametric structural labour supply model where both taxes and transfers are treated in a unified framework. In the second part, we use the two estimated equations for Hungary and the Czech Republic to simulate how each individual's probability of being active - and hence the aggregate labour supply - would change in one country if it adopted the other country's tax-benefit system. More precisely, we perform a microsimulation exercise: we replace the net income variables (wages, transfers and non-labour incomes) in the estimated equations by their values that would result from adopting the other country's tax and transfer system. As a consequence of the benefits gained or losses suffered due to changes in the effective tax rates and the amount of (potential) transfers, individuals are expected to adjust their labour supply according to the estimated probit equations. The weighted average of the individual changes in the participation probabilities corresponds to the aggregate labour supply shock induced by the hypothetical reform. Under certain assumptions detailed later, the result of this exercise reveals the extent to which the difference between the two countries' participation rates can be explained by the differences in the taxation and welfare benefit systems.

\subsection{Modelling Labour Supply at the Extensive Margin}

An individual's labour-supply decision is usually modelled as a trade-off between the utility gained from consumption or leisure. Starting from a standard utility function characterised by strictly positive marginal utilities with respect to consumption and leisure, the participation decision is determined by the difference between the market wage and the reservation wage. In the standard textbook approach based on marginal calculus, non-participation follows simply from the corner solution of the model (Hausman, 1981). The theory yields a binary dependent variable specification in which the probability of working or actively seeking work is modelled as a function of the net market wage, net non-labour income and individual preferences. In this 
framework, taxes influence labour supply by affecting net market wages and net non-labour incomes. $^{4}$

The early generation Hausman model proved to be too restrictive in many respects. First, relying on tangency conditions, the Hausman model is restricted to the case of (piecewise) linear and convex budget sets. This assumption is particularly restrictive if certain transfers get lost immediately on taking up a job - which is usually the case - and the wage earned during the first few hours worked does not compensate for the discrete loss in benefits. As a consequence, the standard reservation wage - defined as the lowest wage rate at which a worker would be willing to work nonzero hours - is undefined. ${ }^{5}$ Second, quasi-concavity of the utility function is implicitly imposed a priori. As discussed by MaCurdy et al. (1990), the Hausman model requires the Slutsky condition to hold at all internal points of the budget constraint. This restriction is, however, typically rejected by empirical studies (see e.g. Blundell and MaCurdy, 1999) and may lead to biased estimates by implicitly limiting the range of elasticities that can be obtained. Third, predictions using the standard approach do not fit the data well, as the model does not account for the fact that very few observations exist with a small positive number of hours worked. Finally, the model makes it difficult to handle household members' joint labour supply decisions.

In response to these shortcomings, the discrete choice approach to modelling labour supply provides a convenient alternative to the continuous hours methodology. Originally proposed by van Soest (1995), this approach has become increasingly popular and quite standard in recent years. In this framework, utility-maximising individuals are supposed to choose between a few alternative discrete sets of hours of work, such as inactivity (zero hours worked), part-time or fulltime. Reducing the maximisation problem to choosing among a discrete set of possibilities yielding different utilities considerably simplifies the problem and provides a simple yet rather general way of representing labour supply decisions in the presence of nonlinear and non-convex budget constraints.

Mathematically, the utility ( $U$ ) that individual (or household) $i$ derives from choosing alternative $j$ from $J$ possible discrete choices is represented by a random utility model of the form:

$$
U_{i j}=V_{i j}\left(c_{i j}, 1-l_{j}, Z_{i}, \theta\right)+\varepsilon_{i j}
$$

where $V_{i j}$ is a positive deterministic term that represents the mean utility across observationally identical agents when alternative $j$ is chosen and $\varepsilon_{i j}$ is a random term that is not correlated with the deterministic part of the utility function. $V_{i j}$ is conditional on the alternative-specific consumption $\left(c_{i j}\right)$ and leisure $\left(1-l_{j}\right.$, with total time endowment normalised to 1$)$, a set of individual characteristics $\left(Z_{i}\right)$ and preference parameters $\theta$.

In our empirical work, we model individual labour supply decisions. We assume that there are only two labour-market states, active and inactive. Indeed, in both the Czech Republic and Hungary, part-time work is relatively rare: before the outbreak of the current crisis, the share of

\footnotetext{
${ }^{4}$ For a comprehensive presentation of the different variants of the standard modelling approach and their identification strategies, see e.g. Blundell and MaCurdy (1999) and Blundell et al. (2007)

${ }^{5}$ To overcome this deficiency, fixed costs of work can be introduced, yet this additional source of non-convexity is also difficult to handle (see e.g. Bourguignon and Magnac, 1990). Van Soest and Das (2001) argue that nonconvexities in general imply rather restrictive and implausible forms for preferences.
} 
part-time employees among all workers was less than 5\% in both countries. By 2013, this share had increased to $6.6 \%$ in the Czech Republic and to $6.7 \%$ in Hungary. For comparison, the share of part-time employees in the EU15 reached $21 \%$ in 2008 and increased further to $23.6 \%$ in $2013 .^{6}$

The participation decision boils down, therefore, to a comparison of the utility gained from working full-time $(j=1)$ to the utility gained from staying out of the labour force and getting the full amount of transfers $(j=0)$. Individual $i$ therefore chooses to work full-time if $U_{i 1} \geq U_{i 0}$. Given the budget constraint stating that consumption must equal total income, the probability of participation is given by:

$$
P_{i, j=1}=P\left\lfloor V\left(w_{i}+T_{i}-\Delta T_{i}, 1-l_{1}, Z_{i}, \theta\right)+\varepsilon_{i 1} \geq V\left(T_{i}, 1, Z_{i}, \theta\right)+\varepsilon_{i 0}\right\rfloor
$$

where $P_{i, j=1}$ represents the probability that individual $i$ is economically active; $w_{i}$ being the net market wage of individual $i$ if working full-time $\left(l=l_{1}\right) ; \Delta T_{i}$ is the sum of all the hypothetical social transfers the individual gets (or would get) at zero hours worked and loses when working full-time; and $T_{i}$ is the total net non-labour income, including social transfers $\left(\Delta T_{i}\right)$ and other non-labour income (pensions, dividend payments, income of other members of the household, etc.)

If the random components $\varepsilon_{i j}$ are i.i.d. extreme value distributed with c.f.d. $\exp \left\{-\exp \left(-\varepsilon_{i j}\right)\right\}$ with fixed variance, McFadden (1974) derives a formal expression of the probability that alternative $j$ is chosen and shows that the parameters can be estimated by maximum likelihood techniques. ${ }^{7}$

Benczúr et al. (2014) transform eq. (2) by linearising the left-hand side of the expression:

$$
V\left(W_{i}+T_{i}, 1-l_{1}, Z_{i}, \theta\right) \approx V\left(T_{i}, 1-l_{1}, Z_{i}, \theta\right)+W_{i} V_{c}^{\prime}\left(T_{i}, 1-l_{1}, Z_{i}, \theta\right)
$$

where $W_{i}=w_{i}-\Delta T_{i}$ represents the "gains to work", defined as the difference between the net wage and the amount of transfers lost when working. The comparison becomes:

$$
W_{i} \geq \frac{V\left(T_{i}, 1, Z_{i}, \theta\right)-V\left(T_{i}, 1-l_{1}, Z_{i}, \theta\right)}{V_{c}^{\prime}\left(T_{i}, 1-l_{1}, Z_{i}, \theta\right)}
$$

The individual therefore chooses to participate if the gains from accepting a full-time job (the gains to work) exceeds a certain threshold, which can be interpreted as the "reservation gains to work". This concept is similar to the standard textbook approach and can be interpreted as the discretised version of the Hausman method.

By log-linearising the right-hand side of eq. (4), Benczúr et al. (2014) derive a formal expression for the probability of being active, which yields the following structural probit equation:

\footnotetext{
${ }^{6}$ Source: Eurostat

${ }^{7}$ This model, however, exhibits the unpleasant property of Independence of Irrelevant Alternatives (IIA). To overcome this deficiency, empirical studies usually introduce some unobserved heterogeneity in preferences, that is, some of the parameters are assumed to be randomly distributed. The estimation technique for this model, referred to as "mixed logit" or "random parameter logit", is described in detail in McFadden and Train (2000).
} 


$$
P_{i, j=1}=\Phi\left(\gamma \log W_{i}+Z_{i} \alpha^{\prime}+\psi \log T_{i}\right)
$$

In this framework, instead of directly estimating the parameter of the utility function, we approximate the "reservation gains to work" by using a set of observed individual characteristics $\left(Z_{i}\right)$ and the total net non-labour income $\left(T_{i}\right) .^{8}$

In practice, not all the variables of eq. (5) are observed for all individuals. As in Benczúr et al. (2014), we construct the missing variables as follows:

1. for employed individuals, we directly observe their gross wages, so we can compute their net wages $\left(w_{i}\right) .^{9}$ However, we do not observe the hypothetical amount of transfers the individual would get if he or she decided to stop working. Using individual characteristics and the details of the welfare system, we calculate the amount of lost transfers $\left(\Delta T_{i}\right)$ the individual would be entitled to being non-employed. Consequently, the gains to work are calculated as $W_{i}=w_{i}-\Delta T_{i}$, while the amount of lost transfers $\left(\Delta T_{i}\right)$ is added to the observed non-labour income to obtain $T_{i}$.

2. for the non-employed, the total amount of transfers is observed, whether income-tested or not. ${ }^{10}$ We do not observe, however, the market wage $w_{i}$. Similarly to Benczúr et al. (2014), the gains to work are estimated using the Heckman selection model (see Section 2.2).

\subsection{Estimation Method}

Equation (5) is estimated using a three-step procedure. The first two steps represent in fact a Heckman sample selection model to predict the gains to work. The only difference compared to the standard Heckman procedure is that instead of wages, we directly estimate the gains to work. The latter are supposed to be influenced by a vector $X_{i}$, which includes variables affected by both labour supply and labour demand factors. The gains-to-work equation is thus specified as:

$$
\log W_{i}=X_{i} \beta^{\prime}+\mu_{i}
$$

The three-step procedure is thus as follows:

1. first, we run a reduced-form probit equation explaining the probability of being employed $(e=1)$ :

\footnotetext{
${ }^{8}$ Benczúr et al. (2014) show that this representation yields plausible results and similar own-wage elasticities as usually found in the discrete choice literature. Nevertheless, estimating the utility functions using the usual McFadden approach for both countries and comparing our main results using both techniques represents a straightforward extension of this paper.

${ }^{9}$ Gross wages include employer contributions as well. Accordingly, we take into account both employer and employee-side contributions and taxes when computing net wages.

${ }^{10} \mathrm{We}$ can also determine $\Delta T_{i}$ the same way we computed it for employed individuals by applying the welfare rules. We used the observed values for the estimation part; however, we used our own calculation for the simulation part. See Section 2.3 for details.
} 


$$
P_{i, e=1}=\Phi\left(X_{i} \beta_{R F}^{\prime}+Z_{i} \alpha_{R F}^{\prime}+\psi_{R F} \log T_{i}\right)
$$

2. second, we use the inverse Mills ratio $\lambda(x)=\phi(x) / \Phi(x)$ as a correction in the gains-towork equation:

$$
\log W_{i}=X_{i} \beta^{\prime}+\lambda\left(X_{i} \hat{\beta}_{R F}^{\prime}+Z_{i} \hat{\alpha}_{R F}^{\prime}+\hat{\psi}_{R F} \log T_{i}\right)+\mu_{i}
$$

3. third, we use the predicted gains to work $\log \hat{W}_{i}=X_{i} \hat{\beta}^{\prime}$ to estimate the structural probit equation $^{11}$ :

$$
P_{i, j=1}=\Phi\left(\gamma \log \hat{W}_{i}+Z_{i} \alpha^{\prime}+\psi \log T_{i}\right)
$$

To put it differently, the estimation procedure corresponds to a IV probit where the first step is a Heckman selection model. The endogeneity and measurement error biases associated with $\log W_{i}$ are therefore corrected. ${ }^{12}$ The key element of the identification is the presence of "labour demand shifters" in $X_{i}$ which are missing from the structural equation and act like excluded instruments, that is, variables which determine the market wage but only affect labour supply indirectly through wages.

The labour supply shifters $\left(Z_{i}\right)$ include education dummies, household head, mother with infant ( $<3$ years old), attending full-time education, household size (number of persons), pensioner, family status (husband, wife, child, single, divorced, etc.) and age-group (15-24, 25-49, 50+) dummies and year dummies.

Following Benczúr et al. (2014), the labour demand shifters $\left(X_{i} \backslash \mathrm{Z}_{\mathrm{i}}\right)$ contain age, age squared and education dummies and their interactions, and county dummies. The county dummies are proxies for local labour market conditions, while age and age square and their interactions with the education dummies are proxies for experience that influence market wages. Once we control for individuals' lifecycle position (student, family status, age group, retired, etc., all variables included in $Z_{i}$ ), we assume - in line with Benczúr et al. (2014) - that an extra year has a negligible impact on labour supply directly, but it strongly affects the wage and hence influences labour supply indirectly.

Once estimated, the structural probit estimation gives us the coefficients of $\log W$ and $\log T$ ( $\gamma$ and $\psi$ respectively) as well as the conditional marginal effects of these variables - evaluated at a certain vector, e.g. at the sample means - on the probability of being active. To obtain the impact of the net wage $(w)$ itself, Benczúr et al. (2014) show that the marginal effect of $\log W$ has to be multiplied by $w /(w-\Delta T)$. Similarly, the effect of conditional transfers on activity is given by

\footnotetext{
${ }^{11}$ Note that we used the unconditional prediction, that is, the effect of the inverse Mills ratio is not included.

${ }^{12}$ The wage error term may indeed be correlated with the participation error term. Note also that $\log W$ is subject to measurement error for various reasons. For example, observed wages are biased downward for part-time workers or for individuals who work less than $\sim 20$ days per month. Lost transfers $(\Delta T)$ - which are part of $\log W$ - may also be mismeasured due to possible lower take-up rates of some benefits and due to the fact that some transfers may be provided with discretion by social offices. It is possible, however, to compare the simulated $\Delta T$ with the observed transfers for individuals who worked for some part of the year and were non-employed for the rest of the year, as both their wages and their transfers are observed. This comparison revealed that for both countries and for most individuals, the simulated transfers were close to the observed ones.
} 
$(\partial \Phi / \partial \log W)(1-w /(w-\Delta T))+(\partial \Phi / \partial \log T)(\Delta T / T)$. We report these marginal effects in Section 4.

\subsection{Simulations}

The simulations are carried out symmetrically using both the Hungarian and the Czech results. As a first step, we predict the participation probabilities using eq. (5) estimated for the Hungarian and Czech data as follows:

$$
\begin{gathered}
\hat{P}_{i, j=1}^{C Z, C Z}=\Phi\left(\hat{\gamma}^{C Z} \log W_{i}^{C Z}+Z_{i} \hat{\alpha}^{C Z}+\hat{\psi}^{C Z} \log T_{i}^{C Z}\right) \\
\hat{P}_{i, j=1}^{H U, H U}=\Phi\left(\hat{\gamma}^{H U} \log W_{i}^{H U}+Z_{i} \hat{\alpha}^{\prime H U}+\hat{\psi}^{H U} \log T_{i}^{H U}\right)
\end{gathered}
$$

$\hat{P}_{i, j=1}^{C_{1}, C_{2}}$ denotes the predicted probability of individual $i$ in country $C_{l}=\{\mathrm{CZ}, \mathrm{HU}\}$ being active and using the tax and transfer system of country $C_{2}=\{\mathrm{CZ}, \mathrm{HU}\}$. Parameters with superscripts $\mathrm{CZ}$ and $\mathrm{HU}$ are estimated parameters for the Czech and Hungarian data respectively. $W_{i}^{\mathrm{C}_{1}}$ and $T_{i}^{\mathrm{C}_{1}}$ are the gains-to-work and the non-labour income (including conditional transfers) variables calculated using country $C_{l}$ 's tax and transfer system. For example, in eq. (10a), we took the observed gross wages for employed Czech individuals and the estimated gross market wages for non-employed individuals and we applied the Czech tax-benefit system to compute $W_{i}^{C Z}$ and $T_{i}^{C Z}$ for each individual. In eq. (10a) and (10b), we set the constant term so that the weighted average of the predicted probabilities exactly matches the aggregate participation rate for the whole population.

In addition to labour income taxes, we took into account indirect taxes (that is, the average effective VAT rate, denoted as $v$ ) in our simulation exercise. The gains to work therefore become $W=(w-\Delta T) /(1+v)$. Similarly, non-labour incomes are also divided by $(1+v) .^{13}$

As a second step, we convert all income variables in the Czech database to Hungarian forint (HUF) using the 2008 average exchange rate (CZK $1=$ HUF 8.04). ${ }^{14}$ Then we apply the Hungarian tax-benefit system to the Czech data to compute net income variables and thus to obtain $W_{i}^{H U}$ and $T_{i}^{H U}$. Before calculating the implied predicted probabilities of being active, we convert the variables back to CZK. We perform symmetrically the same exercise by applying the Czech tax-benefit system to the Hungarian data. The predicted probabilities are given by:

$$
\begin{aligned}
& \hat{P}_{i, j=1}^{C Z, H U}=\Phi\left(\hat{\gamma}^{C Z} \log W_{i}^{H U}+Z_{i} \hat{\alpha}^{\prime C Z}+\hat{\psi}^{C Z} \log T_{i}^{H U}\right) \\
& \hat{P}_{i, j=1}^{H U, C Z}=\Phi\left(\hat{\gamma}^{H U} \log W_{i}^{C Z}+Z_{i} \hat{\alpha}^{\prime H U}+\hat{\psi}^{H U} \log T_{i}^{C Z}\right)
\end{aligned}
$$

The differences between these predicted probabilities and those obtained in the previous step that is, $\left(\hat{P}_{i, j=1}^{C Z, H U}-\hat{P}_{i, j=1}^{C Z, C Z}\right)$ and $\left(\hat{P}_{i, j=1}^{H U, C Z}-\hat{P}_{i, j=1}^{H U, H U}\right)$ - correspond to the individual labour supply shocks induced in one country by adopting the other country's tax-benefit system. The weighted

\footnotetext{
${ }^{13}$ In the estimation part, the effect of VAT is captured by year dummies.

${ }^{14}$ Alternatively, measures that also reflect differences in economic development, such as the ratio of the two countries' nominal GDP per capita, could be used. We also performed the simulations using this alternative measure, but do not present them in this paper. The results - available from the authors upon request - changed only marginally.
} 
averages of these expressions give the aggregate labour supply shocks triggered by the hypothetical reforms.

Whether the initial labour supply shock fully translates into participation in the long run depends on the general equilibrium interactions of the entire economy. For example, in a textbook neoclassical general equilibrium long-run model of a small open economy, the overall effect primarily depends on the assumption made on the long-run elasticity of capital supply. In the perfectly elastic case - which is a standard assumption in the literature - the expected rate of return on capital is pinned down by international benchmarks, which implies that the capital-tolabour ratio and the ratio of factor prices stay constant in the long run. It follows that, for example, after a positive labour supply shock induced by a tax cut, capital accumulation will follow until the new equilibrium is reached with an unchanged capital-labour ratio. After the adjustment period, gross wages will also reach their pre-reform level, so factor prices remain unchanged in the long run. In this framework, the initial labour supply shock fully translates in the long run into participation. Consequently, under these assumptions, the results of our simulation exercises can be interpreted as the effect of differences in the tax-benefit systems in the two countries on the differences in the two countries' participation rates. ${ }^{15}$

\section{Key Elements of the Czech and Hungarian Tax and Transfer Systems}

The Czech and Hungarian tax-benefit systems are both characterised by individual personal income taxation and a broad range of welfare benefits. In what follows, we briefly describe and compare the two systems effective in 2008, the reference year we used for our simulation. In this section, we only consider the main characteristics of the systems that apply to regular wage earners; the self-employed and other specific cases are not considered. In our empirical work, more details are taken into consideration. For a more comprehensive description of the two systems, see, for example, the country chapters of the OECD's Benefits and Wages publication. ${ }^{16}$ For a detailed presentation of the calculation methods for net incomes and (hypothetical) transfers, see Benczúr et al. (2014) for the Hungarian case and Galuščák and Pavel (2012) for the Czech case. Additional details on the transfer systems of the two countries are presented in the Appendix.

In both countries, labour incomes are subject to personal income tax and employer and employee contributions. In Hungary, the tax schedule comprises three brackets, with tax rates of $18 \%, 36 \%$ and $40 \% .{ }^{17}$ Employees with annual earnings under a given threshold are eligible for an earning income tax credit (EITC) of $18 \%$ of their wage income, which is phased out at a rate of $9 \%$. A child tax credit (fixed amount) is available for families with three or more children. Social security contributions related to sickness, unemployment and pensions are applied.

In the Czech Republic, family taxation for married couples with children was introduced in 2005. The joint taxation, however, became irrelevant when a flat tax rate of $15 \%$ was introduced in 2008. It is applied to so-called super-gross income, which includes employer social security

\footnotetext{
${ }^{15}$ For a detailed explanation of the long-run general equilibrium effects of a tax reform and the implications of capital supply elasticity for the new equilibrium, see a closely related paper: Benczúr et al. (2012).

${ }^{16}$ www.oecd.org/els/social/workincentives

${ }^{17}$ The third bracket is in fact the second bracket plus a $4 \%$ surtax - a.k.a. the "solidarity levy" - which was introduced in 2007.
} 
contributions. Tax credits are available per person, per spouse under a given income and per dependent child. If the tax credit per child is negative, it is provided to the household as a tax bonus.

Comparing the two personal income tax (PIT) systems, Figure 1 reveals that, first, the Hungarian system is more progressive and, second, average taxes are higher, especially - but not only - for higher income earners. Moreover, the Czech average tax rate can be negative for families with children if the calculated income tax is lower than the amount of family benefit the taxpayer is eligible for. The higher average PIT rates in Hungary are also reflected in higher tax revenues: the Hungarian government in 2008 collected $7.9 \%$ of GDP as PIT tax revenue, compared to $3.7 \%$ in the Czech Republic (see Table 1).

Figure 1: Average Earning Tax Rate (AETR) in CZ and HU (2008)

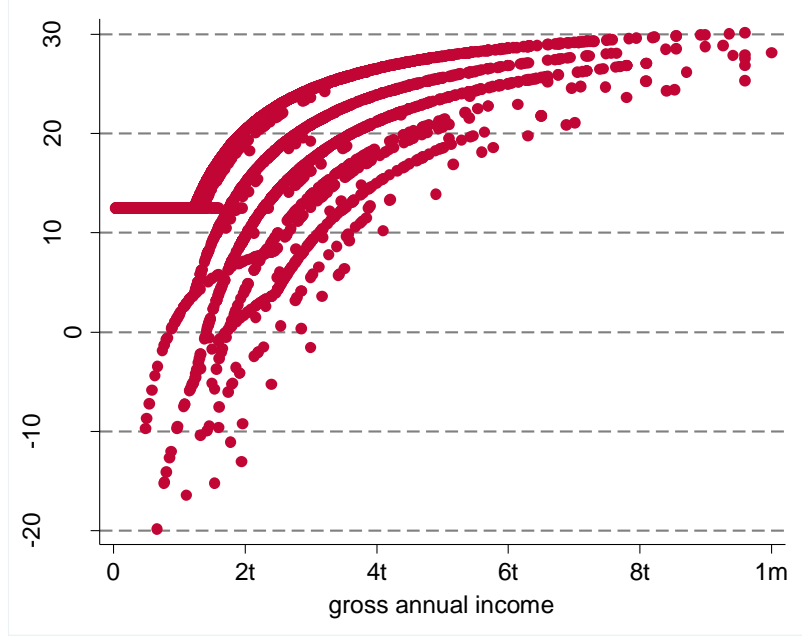

(a) $\mathrm{CZ}$

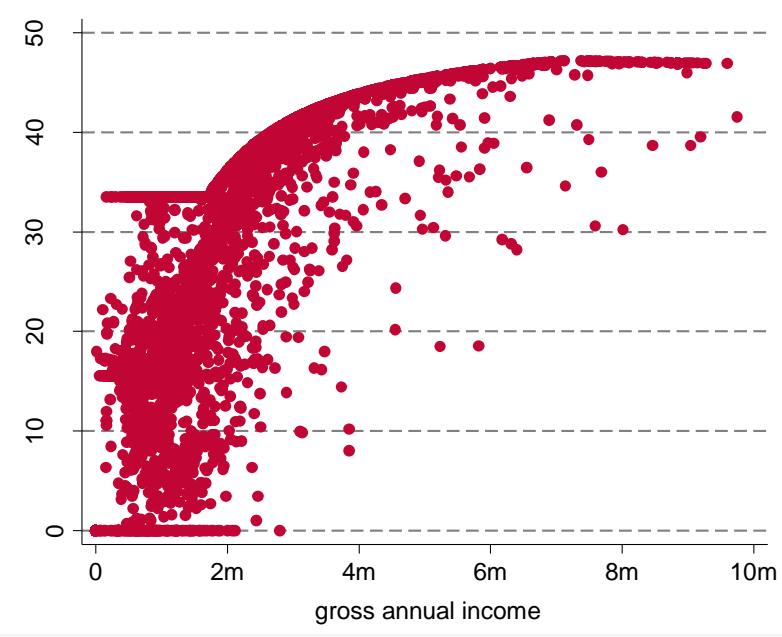

(b) $\mathrm{HU}$

Note: The average earning tax rate is the total amount of tax paid on labour earnings as a percentage of the tax base if all forms of income taxes, contributions, tax credits and bonuses are taken into account.

Both countries provide a wide range of social benefits in order to - at least partly - compensate for temporary loss of labour income, to reduce and prevent poverty or to achieve other goals. Overall, if we look at the share of GDP spent on various transfers in 2008, the Hungarian benefit system seems more generous than the Czech one (Table 1). ${ }^{18}$

\footnotetext{
${ }^{18}$ The Hungarian benefit system is often cited as being relatively generous compared to the systems of neighbouring countries based on the share of GDP redistributed, on the eligibility criteria for some benefits and on the amount of welfare transfers an individual might be eligible for. At the same time, Hungary is not successful in ensuring access to transfers by the most vulnerable. In comparison with the Czech Republic, the share of people at risk of poverty or social exclusion is more than two times higher in Hungary than in the Czech Republic according to Eurostat data (33.5\% vs $14.6 \%$ in 2013). The Hungarian redistribution is arguably far from the egalitarian principle.
} 
Table 1: Key Differences in the Tax and Transfer Systems (2008)

\begin{tabular}{|c|c|c|c|c|}
\hline & \multicolumn{2}{|c|}{ Description } & \multicolumn{2}{|c|}{$\%$ of GDP } \\
\hline & $\mathrm{CZ}$ & $\mathrm{HU}$ & $\mathrm{CZ}$ & $\mathrm{HU}$ \\
\hline \multicolumn{5}{|c|}{ Taxes on labour } \\
\hline PIT & $\begin{array}{c}\text { one tax rate }(15 \% \text { on } \\
\text { supergross })+ \text { allowances } \\
\text { (children), negative AETR } \\
\text { possible }\end{array}$ & $\begin{array}{l}\text { three tax rates }(18 \%, \\
36 \%, 40 \%) \text { with ETC + } \\
\text { allowances, no } \\
\text { negative AETR }\end{array}$ & $3.7 \%$ & $7.9 \%$ \\
\hline employee contr. & $12.5 \%$ & $17 \%$ & $3.5 \%$ & $3.2 \%$ \\
\hline employer contr. & $35 \%$ & $\begin{array}{l}32 \%+1950 \\
\text { HUF/month }\end{array}$ & $9.9 \%$ & $9.9 \%$ \\
\hline \multicolumn{5}{|c|}{ Other taxes } \\
\hline eff. tax on cons. & $15.4 \%$ & $18.2 \%$ & $10.6 \%$ & $15.6 \%$ \\
\hline eff. tax on sales & -- & $1.7 \%$ & -- & $1.7 \%$ \\
\hline eff. tax on capital & $9.8 \%$ & $7.3 \%$ & $4.2 \%$ & $2.6 \%$ \\
\hline
\end{tabular}

\section{Benefits}

\begin{tabular}{|c|c|c|c|c|}
\hline maternity benefit & $\begin{array}{l}6 \text { months: } 69 \% \text { of previous } \\
\text { gross income (capped) }\end{array}$ & $\begin{array}{c}\text { first } 2 \text { years: } 70 \% \text { of } \\
\text { previous income (capped), } \\
\text { third year: fixed amount; } \\
\text { longer entitlement period } \\
\text { for disabled child, twins or } \\
\text { three children }\end{array}$ & $0.2 \%$ & $0.7 \%$ \\
\hline UB & $\begin{array}{c}\text { first } 3 \text { months: } 50 \% \text { of } \\
\text { previous net income; next } 3 \\
\text { months: } 45 \% \text { of previous } \\
\text { net income. Capped; longer } \\
\text { entitlement period for the } \\
\text { elderly }\end{array}$ & $\begin{array}{l}\text { max } 3 \text { months: } 60 \% \text { of } \\
\text { previous income (capped); } \\
\text { then max } 6 \text { months: fixed } \\
\text { amount; then max } 3 \text { more } \\
\text { months: lower fixed } \\
\text { amount; longer entitlement } \\
\text { period for the elderly }\end{array}$ & $0.2 \%$ & $0.4 \%$ \\
\hline $\begin{array}{l}\text { other social } \\
\text { benefits }\end{array}$ & fixed amount & fixed amount & $1.2 \%$ & $1.2 \%$ \\
\hline old-age pension & $\begin{array}{l}\text { official: } 61 \text { years and } 10 \\
\text { months for men, } 60 \text { years } \\
\text { for women (less with } \\
\text { children); effective: } 62.6 \\
\text { for men, } 58.8 \text { for women }\end{array}$ & $\begin{array}{c}\text { official: } 62 \text { years; } \\
\text { effective: } 59.5 \text { for men, } \\
58.5 \text { for women }\end{array}$ & $5.8 \%$ & $9.7 \%$ \\
\hline $\begin{array}{l}\text { disability } \\
\text { pension }\end{array}$ & & & $1.5 \%$ & $2.4 \%$ \\
\hline
\end{tabular}

Source: National Accounts (HU and CZ), ESCB Public Finance Report (2014), Czech Ministry of Labour.

Notes: The effective tax on consumption is the sum of indirect taxes divided by final consumption expenditure; the effective tax on capital is corporate tax revenues divided by the share of capital revenues based on the National Accounts. Other social benefits include: (CZ) total state social support (including parental allowance and birth grant) and material need benefits and (HU) regular social assistance benefit, social supplement, other benefits (e.g. retraining), care allowances and other irregular social benefits. 
As a general rule, in Hungary, maternity benefits and unemployment benefits either are fixed amounts or depend on previous income and are subject to income taxation. Other social benefits and pensions are, on the other hand, exempt from taxation. In the Czech Republic, all benefits are non-taxable (except very high pensions). In the case of maternity benefits, the amount is calculated based on previous gross income, whereas unemployment benefits are calculated based on previous net income. These differences make direct comparison of the two systems rather challenging. Some details of the two welfare benefit systems are listed in Table 1. For a more detailed description, see the Appendix or the references presented in the first paragraph of this section.

\section{Results}

The estimations are carried out using SILC ("Survey of Income and Living Conditions") data for the Czech Republic for the years 2005-2010. The SILC is a yearly cross-section survey of households which provides detailed information on demography and incomes. For each year, the survey contains broadly 10,000 households and 23,000 individuals.

All income variables (labour and non-labour incomes, transfers) are expressed in total annual terms. To compute net incomes and potential transfers that individuals are entitled to or would be entitled to in the absence of any income from work, we used a modified version of the tax-benefit model developed by Galuščák and Pavel (2012). We used the same codes to compute net labour incomes, but we extended the original version of the model in order to take into account more complex features of the Czech tax and transfer system (e.g. taxes on capital revenues, maternity benefit, etc.). As for the transfers, we simulated the total yearly amount of benefits the individual gets if he is not working or could get if he decided to stop working. ${ }^{19}$ At the end, we obtained the same model as in Benczúr et al. (2014) for Hungarian data.

The estimation results reported for Hungary are from Benczúr et al. (2014). ${ }^{20}$ The Hungarian Household Budget Survey (HBS) is more detailed but otherwise perfectly comparable to the CZSILC database. First, several income variables in the Czech database are broken down into several categories in its Hungarian counterpart. Second, some variables - such as income from abroad, income of minors, life annuity payments, scholar grants and severance indemnities - are reported in the Hungarian database but no information is available from the Czech database. For the simulation exercise, we carefully linked all the variables to their counterparts in the other database. If one-to-one correspondence could not be achieved, the closest possible several-to-one match was established.

\subsection{Estimation Results}

Table 2 reports the baseline estimates, following the methodology presented in Section 2.2. As expected, higher gains to work increase the probability of participation in the labour market, while non-labour income has the opposite effect.

\footnotetext{
${ }^{19}$ The original tax-benefit model in Galuščák and Pavel (2012) instead simulates the amount of monthly benefits an individual can get at the moment of the survey.

${ }^{20}$ The estimations for Hungary were carried out using the HBS database for the years 1998-2008.
} 
Overall, the results are remarkably close to the Hungarian ones. The point estimates and the conditional marginal effects of gains to work - evaluated at the population averages - are basically the same in the two countries. This is also true for the conditional marginal effect of net wages, suggesting that, on average, a similar change in the average tax rate has the same effect in both countries.

As for non-labour income, the estimated coefficient and the marginal effect are lower in absolute value in the Czech Republic than in Hungary, but the results for the conditional marginal effect of transfers are very close to each other. This seemingly confusing result is a reflection of the more detailed non-labour income (independent of working status) data used for the Hungarian estimation. As explained in Section 2.2, the marginal effect of conditional transfers $(\Delta T)$ is obtained by using the following formula: $(\partial \Phi / \partial \log W)(1-w /(w-\Delta T))+(\partial \Phi / \partial \log T)(\Delta T / T)$. Given that the Hungarian non-labour income contains more information ( $T$ includes certain types of incomes missing from the Czech database), the share of the potentially lost transfers in total non-labour income $(\Delta T / T)$ is higher in the Czech database. As a consequence, the (lower, in absolute value) Czech result for the marginal effect of non-labour income is multiplied by a relatively higher positive value, which leads to a similar estimate for the conditional marginal effect of transfers.

Table 2: Main Results

(A) Estimation results

\begin{tabular}{ccccc} 
& \multicolumn{3}{c}{ CZ } & \multicolumn{2}{c}{ HU } \\
& \multicolumn{2}{c}{$(1)$} & \multicolumn{2}{c}{ (2) } \\
\cline { 2 - 5 } & coef. & std. err. & coef. & std. err. \\
\hline gains to work & 0.818 & 0.254 & 0.820 & 0.099 \\
non-labour income & -0.301 & 0.038 & -0.844 & 0.110 \\
\hline \multirow{2}{*}{ gains to work } & dy/dx & (B) Conditional marginal effects & \\
non-labour income & 0.268 & std. err. & dy/dx & std. err. \\
net wage & -0.099 & 0.071 & 0.290 & 0.028 \\
transfer & 0.373 & 0.099 & -0.298 & 0.030 \\
\hline \hline
\end{tabular}

Source: CZ-SILC database, 2005-2010. The Hungarian results are from Benczúr et al. (2014).

Notes: Three-step estimates, as described in the paper, using a sample of individuals aged 15-74. Standard errors are bootstrapped with 200 replications. The structural probit equation includes: log of gains to work, log of non-labour income, mother with infant (less than 3 years old), full-time student and education (less than elementary school, elementary school, vocational, secondary education, tertiary education) dummies, age-group dummies (15-24, 25-49, 50+), pensioner, gender and head of household dummies, household size and family status dummies (single, married living together, married living separately, widow(er), divorced), household membership status dummies (husband, wife, companion, single parent, child, ascendant, other relation, non-relation, single), year dummies. The controls included in the reduced-form probit and the wage equation which are missing from the structural probit are: county dummies, interaction of age and age square with education dummies. 
We are ultimately interested in the effects of tax and transfer changes, that is, the conditional marginal effects of the net wage and transfers. On average, a 10\% increase in the net wage leads to a 3.7 percentage point increase in the probability of being active in the Czech Republic and a 3.9 percentage point increase in Hungary. A $10 \%$ increase in transfers decreases the average individual's probability of being active by 1.2 percentage points in the Czech Republic and by about 1.4 percentage points in Hungary. These strikingly similar results suggest that individual preferences are quasi-identical in the two countries.

Following Benczúr et al. (2014), we report in Table 3 the conditional marginal effects by selected subgroups depending on level of education, gender and marital status. Again, the results are very close to the Hungarian ones. Panel A shows that the responsiveness of participation to changes in both net wages and transfers is lower for persons with higher (tertiary) education. Similarly to the results reported in Benczúr et al. (2014), the conditional marginal effects calculated on the primeage population averages (25-54 years old, reported in Panel B) are lower (in absolute value) than the results for the whole population, indicating that prime-age individuals are less responsive to tax and transfer changes than the rest of the population. Within the prime-age population, however, the education level strongly influences individuals' responsiveness: the lower educated ("elementary school or less"), probably highly transfer-dependent, group is highly responsive, while the estimated elasticities for secondary and tertiary educated people are much smaller.

The remaining rows in panel B suggest that women's participation is more responsive that that of men, particularly for married women and women of child-bearing age. Finally, the results in panel $\mathrm{C}$ show that the reaction of elderly persons to changes in the net wage and transfers is even higher.

The estimation results and the implied wage elasticities are qualitatively in line with existing results in the empirical literature. However, direct comparison of the elasticities is not straightforward. There is a large consensus in the literature that women (and especially married women) respond more to changes in their net market wage than men. Lower educated and elderly individuals are also usually found to be more responsive than the average. The variation in the magnitude of the estimated labour supply elasticities found in the literature is nonetheless considerable and these reported elasticities are rarely directly comparable for several reasons. First, with some exceptions, early labour supply models using the continuous Hausman approach usually do not distinguish between the decision to participate (the extensive margin) and the decision regarding hours worked (the intensive margin) and only report uncompensated and/or compensated (Hicksian) hours elasticities, not the participation elasticity. ${ }^{21}$ Second, although the discrete choice approach always includes, by construction, the participation elasticity, estimates from various studies are not easily comparable due to differences in specifications and definitions. A recent comprehensive comparison of the international evidence on labour supply elasticities by Bargain and Peichl (2013) shows that the large variance in the reported elasticities is - at least partly - explained by differences in specifications (most importantly, whether wages are predicted

\footnotetext{
${ }^{21}$ For a comparative overview of the hours elasticities stemming from the Hausman approach, see e.g. Pencavel (1986) for married men, Killingsworth and Heckman (1986) for married women, or the more recent survey by Everest et al. (2008). Other literature surveys include Blundell and MaCurdy (1999), Blundell, MaCurdy and Meghir (2007), Keane (2011) and Meghir and Phillips (2010), which focus mostly on analyses based on the standard continuous approach, but also include some more recent evidence from discrete choice methodology.
} 
Table 3: Conditional Marginal Effects by Selected Subgroups

\begin{tabular}{|c|c|c|c|c|c|}
\hline & & \multicolumn{2}{|c|}{$\mathrm{CZ}$} & \multicolumn{2}{|c|}{$\mathrm{HU}$} \\
\hline & & $\mathrm{dy} / \mathrm{dx}$ & std. err. & $\mathrm{dy} / \mathrm{dx}$ & std. err. \\
\hline & & \multicolumn{4}{|c|}{ (A) Full sample } \\
\hline \multirow{2}{*}{ all individuals } & net wage & 0.373 & 0.099 & 0.395 & 0.038 \\
\hline & transfer & -0.121 & 0.028 & -0.136 & 0.013 \\
\hline \multirow{2}{*}{$\begin{array}{l}\text { elementary } \\
\text { school or less }\end{array}$} & net wage & 0.231 & 0.097 & 0.294 & 0.089 \\
\hline & transfer & -0.077 & 0.030 & -0.093 & 0.028 \\
\hline \multirow{2}{*}{$\begin{array}{l}\text { secondary } \\
\text { education }\end{array}$} & net wage & 0.307 & 0.079 & 0.310 & 0.031 \\
\hline & transfer & -0.102 & 0.023 & -0.118 & 0.012 \\
\hline \multirow{3}{*}{$\begin{array}{c}\text { tertiary } \\
\text { education }\end{array}$} & net wage & 0.157 & 0.032 & 0.139 & 0.015 \\
\hline & transfer & -0.043 & 0.007 & -0.045 & 0.005 \\
\hline & & \multicolumn{4}{|c|}{ (B) Prime-age subsample } \\
\hline \multirow{2}{*}{$\begin{array}{l}\text { prime-age } \\
\text { subsample }\end{array}$} & net wage & 0.099 & 0.023 & 0.127 & 0.014 \\
\hline & transfer & -0.028 & 0.005 & -0.054 & 0.006 \\
\hline \multirow{2}{*}{$\begin{array}{l}\text { elementary } \\
\text { school or less }\end{array}$} & net wage & 0.419 & 0.124 & 0.409 & 0.040 \\
\hline & transfer & -0.149 & 0.039 & -0.194 & 0.019 \\
\hline \multirow{2}{*}{$\begin{array}{l}\text { secondary } \\
\text { education }\end{array}$} & net wage & 0.091 & 0.023 & 0.122 & 0.012 \\
\hline & transfer & -0.026 & 0.005 & -0.054 & 0.005 \\
\hline \multirow{2}{*}{$\begin{array}{l}\text { tertiary } \\
\text { education }\end{array}$} & net wage & 0.073 & 0.015 & 0.050 & 0.004 \\
\hline & transfer & -0.019 & 0.003 & -0.019 & 0.001 \\
\hline \multirow{2}{*}{ single men } & net wage & 0.078 & 0.019 & 0.096 & 0.012 \\
\hline & transfer & -0.025 & 0.005 & -0.038 & 0.005 \\
\hline \multirow{2}{*}{ single women } & net wage & 0.212 & 0.058 & 0.168 & 0.019 \\
\hline & transfer & -0.064 & 0.015 & -0.076 & 0.008 \\
\hline \multirow{2}{*}{ married men } & net wage & 0.016 & 0.002 & 0.039 & 0.005 \\
\hline & transfer & -0.004 & 0.000 & -0.016 & 0.002 \\
\hline \multirow{2}{*}{$\begin{array}{l}\text { married } \\
\text { women }\end{array}$} & net wage & 0.236 & 0.067 & 0.290 & 0.025 \\
\hline & transfer & -0.060 & 0.015 & -0.133 & 0.012 \\
\hline \multirow{3}{*}{$\begin{array}{l}\text { women of } \\
\text { child-bearing } \\
\text { age }(25-49)\end{array}$} & net wage & 0.266 & 0.078 & 0.231 & 0.021 \\
\hline & transfer & -0.069 & 0.018 & -0.108 & 0.010 \\
\hline & & \multicolumn{4}{|c|}{ (C) The elderly } \\
\hline \multirow{2}{*}{ elderly (50+) } & net wage & 0.524 & 0.155 & 0.392 & 0.065 \\
\hline & transfer & -0.227 & 0.060 & -0.103 & 0.017 \\
\hline
\end{tabular}

Notes: Conditional marginal effects computed using the estimation on the full sample and evaluated at the subgroup-specific mean values of the covariates; Hungarian results are from Benczúr et al. (2014). 
for all individuals or only for non-workers) and the time period considered. A meta-analysis by Chetty et al. (2012) provides a "consensus" elasticity: according to the authors, existing micro and macro evidence points towards an aggregate steady-state elasticity of labour supply at the extensive margin of 0.25 .

Overall, the marginal effects obtained for the Czech Republic and Hungary lie in the (rather large) range obtained in previous studies, especially studies using the discrete choice approach. ${ }^{22}$ Given the large dispersion of the labour supply elasticities estimated for different countries and time periods and using various methodologies, the similarities of the results we obtain for two different countries is in itself interesting and we tentatively suggest that methodological differences might be responsible for a considerable part of the cross-country variation in the elasticities found in the literature. The findings of Bargain et al. (2012), who estimate a comparable labour supply equation for a large set of countries and show that cross-country differences in genuine work preferences are rather small, corroborate this view.

Finally, to produce an accurate comparison with previous findings, and using the "consensus" elasticity reported by Chetty et al. (2012), Benczúr et al. (2014) simulated the effect of a one per cent increase in the net wage on the aggregate participation probability using the Hungarian data and estimated equation. ${ }^{23}$ The resulting aggregate elasticity of 0.28 is quite in line with the consensus.

\subsection{Simulation Results}

The simulations were carried out as explained in Section 2.3. The results are shown in Table 4. The figures reported indicate the participation rates for 2008 (the reference year chosen for our simulations) ${ }^{24}$ for both countries on the overall sample of individuals aged 15 to 74 (rows (a) to (g)), for the prime-age subsample (rows (h) to (m)) and for elderly people (row (n)).

The participation rates are considerably higher in the Czech Republic than in Hungary according to official Eurostat statistics (see columns (1) and (6)). Columns (2) and (7) show that the simple aggregate participation rates obtained from our datasets are very close to the official Eurostat data. The difference in participation rates is 8.5 percentage points according to the Eurostat data and 6.6 percentage points in our datasets.

The simulation results using each country's own tax and benefit systems are presented in columns (3) and (8). The reported numbers are weighted averages of the participation probabilities predicted by eq. (10a) and (10b). As mentioned in Section 2.3, the constant terms in eq. (10a) and (10b) are set so as to match the aggregate statistics. The simulated full-sample aggregate participations (cells (a3) and (a8)) are therefore equal to the observed participation rates (cells (a2) and (a7)). The differences in the participation rates for the selected subgroups (columns (3) and

\footnotetext{
${ }^{22}$ As noted in Bargain and Peichl (2013), the traditional continuous approach seems to overstate the elasticities compared to discrete choice models. For example, the own-wage elasticities for married women are relatively large using the continuous technique (in several cases, larger than 1), whereas the recent discrete choice approach points towards smaller elasticities (ranging between 0.1 and 0.5 with some exceptions).

${ }^{23}$ The conditional marginal effects presented in Tables 2 and 3 indicate the effect of a one per cent increase in the net wage on the "average individual's" participation probability, as opposed to the change in the aggregate participation probability following a one per cent change in the net wage as reported by Chetty et al. (2012).

${ }^{24} 2008$ is the last year in our database not (or little) influenced by the crisis.
} 
(8)) come from differences in preferences (captured by the labour supply controls in eq. (10a) and (10b)), differences in productivity and thus in gross wages, differences in average tax rates, which influence net wages, and/or differences in potential transfers. For both countries, the simulated participation rates for the selected subgroups are close to the observed ones. This suggests that overall, the estimated equations capture individuals' heterogeneity quite well.

The predicted aggregate participation rates using eq. (11a) and (11b) are reported in columns (4) and (9). In columns (5) and (10) we show how Czech and Hungarian labour force participation would change (in percentage points) if one country adopted the other country's tax-benefit system. The results of our simulation exercise show that, overall, the Czech participation rate would decrease by 2.9 percentage points if the country adopted the Hungarian system, while the Hungarian participation rate would increase by 3.0 percentage points if the Czech system were adopted. These results are highly symmetric and indicate that the differences in the two taxbenefit systems explain about half of the total difference in the two countries' participation rates. The difference is even greater for prime-age individuals, reaching -3.3 percentage points for the Czech data and +3.9 percentage points for the Hungarian data (see row (h)).

The simulation results remain broadly symmetric for most of the selected subgroups. Note that nothing guarantees that the two simulations should be perfectly symmetric for all subgroups. The main reason for the divergence is that these subgroups are not perfectly homogeneous and so the composition of the workforce within the subgroup influences the results. The largest difference is obtained for the elderly: the change in the aggregate participation probability for Hungary is twice the change in the probability for the Czech Republic when the other country's system is adopted. This divergence is at least partly explained by the higher share of pensioners, most importantly disability pensioners (see Table 5). As explained in Section 2.2, the same percentage change in the net wage results in a larger percentage change in the gains to work if the amount of (potentially) lost transfers is relatively high. As the gains-to-work change is larger on average, the participation response is also larger in the case of Hungary. The share of lower educated elderly people is also much higher in Hungary than in the Czech Republic (28\% vs 17\%; see Table 5). As lower educated individuals are more responsive to tax and transfer changes, the change in the aggregate participation rate is larger for Hungarian than for Czech elderly people. The differences in the share of those receiving disability pensions and the share of lower educated individuals are valid for almost all subgroups and thus influence individuals' responsiveness to tax and transfer changes.

Although the responsiveness to changes in the tax-benefit system decreases with education level, rows (b) to (d) of Table 4 do not reveal significant differences in labour supply responses across various educational groups. Moreover, the 2.4-2.8 percentage point difference in the participation rates of the lowest educated individuals explained by the differences in the tax-benefit systems seemingly contradicts the aggregate statistics, which do not support such a difference in favour of the Czech Republic: according to our data, the participation rate is about 2 percentage points higher in Hungary than in the Czech Republic, whereas there is no difference according to the official Eurostat data.

Again, the difference in the composition of the subgroups provides a remedy to the apparent contradictions. In the Czech Republic, the share of full-time students is higher in the lower educated subgroup (column (1), row (b) of Table 5). Full-time students are economically inactive 
and are weakly responsive to changes in the tax or welfare benefit system. Once we filter out fulltime students, the Czech participation rate of lower educated people is 9 percentage points higher than the Hungarian one. With no full-time students included, rows (e) to (g) of Table 4 show that the difference in participation explained by our model is higher for lower educated people (3.6pp$3.7 \mathrm{pp}$ ) than for individuals with secondary education (3.1pp-3.3pp) and for those with tertiary education (2.8pp). These differences reflect the differences in responsiveness to tax and transfer changes.

The highest response is obtained for women, most importantly for married women and/or women of childbearing age (rows (j), (l) and (m)). The large response of these subgroups is most probably related to the very generous maternity benefit system in place in Hungary as compared to the Czech Republic. Although the net amount of the benefit is usually higher in the Czech Republic during the first 6 months after childbirth, the entitlement period is much longer in Hungary: conditional on past employment, Hungarian mothers can receive up to $70 \%$ of their previous income until the second birthday of the youngest child and parents are eligible for a fixed amount until the third birthday of the youngest child. Even longer entitlement periods apply for the third child, for twins and for disabled children.

Finally, note that the other, "unexplained" half of the difference between the two countries' participation rates is also likely to be affected by some elements of the transfer system that we do not explicitly model, most importantly the differences in the old-age and disability pension schemes. Although both types of pensions are included in the model, neither individuals' retirement decision, nor their access to the disability pension scheme is taken into account in our microsimulation exercise. That is, we assume that individuals' retirement decision, their access to the disability pension scheme and the amount of these pensions remain unchanged when the other country's welfare benefit system is adopted. Although several restrictive measures have been adopted to reduce abuse of the disability pension scheme and to increase the effective retirement age, the shares of early-retired and disabled individuals are still relatively high in Hungary by international comparison. 


\section{Table 4: Simulation Results (2008)}

\begin{tabular}{|c|c|c|c|c|c|c|c|c|c|c|}
\hline & \multicolumn{5}{|c|}{ Czech Republic (CZ) } & \multicolumn{5}{|c|}{ Hungary (HU) } \\
\hline & \multirow{3}{*}{$\begin{array}{c}\text { Eurostat } \\
\text { data } \\
\text { (1) }\end{array}$} & \multicolumn{4}{|c|}{ SILC data } & \multirow{3}{*}{$\begin{array}{c}\text { Eurostat } \\
\text { data } \\
(6)\end{array}$} & \multicolumn{4}{|c|}{ HBS data } \\
\hline & & \multirow{2}{*}{$\begin{array}{c}\text { simple } \\
\text { statistics } \\
(2)\end{array}$} & \multicolumn{2}{|c|}{ taxes and transfers } & \multirow{2}{*}{$\begin{array}{l}\text { Difference } \\
(5)=(4)-(3)\end{array}$} & & \multirow{2}{*}{$\begin{array}{c}\text { simple } \\
\text { statistics } \\
(7)\end{array}$} & \multicolumn{2}{|c|}{ taxes and transfers } & \multirow{2}{*}{$\begin{array}{l}\text { Difference } \\
(10)=(9)-(8)\end{array}$} \\
\hline & & & $\begin{array}{l}\mathrm{CZ} \\
(3)\end{array}$ & $\begin{array}{c}\mathrm{HU} \\
(4)\end{array}$ & & & & $\begin{array}{l}\mathrm{HU} \\
(8)\end{array}$ & $\begin{array}{l}\mathrm{CZ} \\
(9)\end{array}$ & \\
\hline (a) Full sample (15-74) & 63.1 & 63.8 & 63.8 & 60.9 & -2.9 & 54.6 & 57.2 & 57.2 & 60.2 & 3.0 \\
\hline (b) elementary or less & 25.4 & 29.7 & 27.8 & 25.4 & -2.4 & 25.4 & 31.8 & 37.0 & 39.9 & 2.9 \\
\hline (c) secondary education & 69.3 & 69.2 & 69.8 & 66.8 & -3.1 & 64.9 & 63.6 & 62.3 & 65.4 & 3.1 \\
\hline (d) tertiary education & 80.1 & 79.2 & 78.4 & 75.5 & -3.0 & 75.9 & 75.1 & 71.3 & 74.1 & 2.8 \\
\hline $\begin{array}{l}\text { (e) elementary school or } \\
\text { less, not full-time student }\end{array}$ & & 49.9 & 44.2 & 40.5 & -3.7 & & 40.9 & 46.8 & 50.4 & 3.6 \\
\hline $\begin{array}{l}\text { (f) secondary education, not } \\
\text { full-time student }\end{array}$ & & 72.4 & 72.7 & 69.6 & -3.1 & & 69.4 & 67.2 & 70.5 & 3.3 \\
\hline $\begin{array}{l}\text { (g) tertiary education, not } \\
\text { full-time student }\end{array}$ & & 82.7 & 82.0 & 79.1 & -2.8 & & 76.2 & 72.2 & 75.0 & 2.8 \\
\hline (h) prime age (25-54) & 87.3 & 87.6 & 88.2 & 84.9 & -3.3 & 80.1 & 84.1 & 81.2 & 85.1 & 3.9 \\
\hline (i) single men & & 92.2 & 91.0 & 88.7 & -2.3 & & 87.9 & 83.8 & 86.7 & 2.9 \\
\hline (j) single women & & 80.8 & 83.1 & 78.6 & -4.5 & & 80.6 & 80.5 & 84.7 & 4.2 \\
\hline (k) married men & & 97.8 & 97.0 & 95.7 & -1.3 & & 92.4 & 87.9 & 90.0 & 2.1 \\
\hline (l) married women & & 79.0 & 81.1 & 76.0 & -5.1 & & 76.4 & 74.0 & 80.0 & 6.0 \\
\hline $\begin{array}{l}\text { (m) women of child-bearing } \\
\text { age }(25-49)\end{array}$ & 78.0 & 77.8 & 80.5 & 75.2 & -5.3 & 73.3 & 77.4 & 77.9 & 83.7 & 5.8 \\
\hline (n) elderly $(50+)$ & 47.3 & 48.7 & 50.2 & 49.0 & -1.2 & 35.2 & 43.2 & 41.1 & 43.5 & 2.4 \\
\hline
\end{tabular}

Notes: Participation rates in 2008 for the Czech Republic and Hungary in \%; percentage points in columns (5) and (10). Results using the overall sample of individuals aged 15-74 in rows (a) to (g), for prime-age individuals aged 25-54 in rows (h) to (m), and for elderly individuals in row (n). Eurostat statistics are reported in columns (1) and (6); the aggregate participation rates obtained from the datasets are in columns (2) and (7). Simulations are presented in columns (3) and (8) for the countries' own tax-benefit systems and in columns (4) and (9) for the other country's tax-benefit system. Columns (5) and (10) show how the labour force participation rate would change for the selected subgroups if the country adopted the other country's tax-benefit system. 
Table 5: Population Shares (2008)

\begin{tabular}{|c|c|c|c|c|c|c|c|c|c|c|c|c|}
\hline & \multirow{2}{*}{\multicolumn{2}{|c|}{$\begin{array}{l}\text { Full-time student } \\
\text { (1) }\end{array}$}} & \multirow{2}{*}{\multicolumn{2}{|c|}{$\begin{array}{l}\text { Receives old-age } \\
\text { pension } \\
\text { (2) }\end{array}$}} & \multirow{2}{*}{\multicolumn{2}{|c|}{$\begin{array}{l}\text { Receives disability } \\
\text { pension } \\
\text { (3) }\end{array}$}} & \multicolumn{6}{|c|}{ Highest level of education } \\
\hline & & & & & & & \multicolumn{2}{|c|}{$\begin{array}{c}\text { elementary school or } \\
\text { less } \\
\text { (4) }\end{array}$} & \multicolumn{2}{|c|}{$\begin{array}{l}\text { secondary education } \\
\text { (5) }\end{array}$} & \multicolumn{2}{|c|}{$\begin{array}{l}\text { tertiary education } \\
\text { (6) }\end{array}$} \\
\hline & $\mathrm{CZ}$ & $\mathrm{HU}$ & $\mathrm{CZ}$ & $\mathrm{HU}$ & $\mathrm{CZ}$ & $\mathrm{HU}$ & $\mathrm{CZ}$ & $\mathrm{HU}$ & $\mathrm{CZ}$ & $\mathrm{HU}$ & $\mathrm{CZ}$ & $\mathrm{HU}$ \\
\hline (a) Full sample (15-74) & 12.3 & 11.0 & 15.7 & 19.1 & 5.3 & 8.4 & 17.2 & 26.2 & 68.8 & 57.2 & 14.0 & 16.6 \\
\hline (b) elementary or less & 40.8 & 22.4 & 16.6 & 23.1 & 6.9 & 12.1 & & & & & & \\
\hline (c) secondary education & 6.0 & 8.5 & 16.5 & 16.8 & 5.5 & 8.4 & & & & & & \\
\hline (d) tertiary education & 8.3 & 1.5 & 10.7 & 20.9 & 2.3 & 2.8 & & & & & & \\
\hline $\begin{array}{l}\text { (e) elementary school or } \\
\text { less, not full-time student }\end{array}$ & & & 28.0 & 29.8 & 11.6 & 15.6 & & & & & & \\
\hline $\begin{array}{l}\text { (f) secondary education, } \\
\text { not full-time student }\end{array}$ & & & 17.6 & 18.4 & 5.9 & 9.2 & & & & & & \\
\hline $\begin{array}{l}\text { (g) tertiary education, not } \\
\text { full-time student }\end{array}$ & & & 11.7 & 21.2 & 2.3 & 2.8 & & & & & & \\
\hline (h) prime age (25-54) & 3.1 & 1.0 & 0.1 & 1.0 & 5.1 & 6.5 & 7.7 & 16.2 & 74.0 & 63.6 & 18.3 & 20.2 \\
\hline (i) single men & 4.5 & 2.6 & 0.0 & 0.7 & 6.4 & 6.8 & 8.5 & 17.1 & 77.7 & 67.6 & 13.8 & 15.3 \\
\hline (j) single women & 6.7 & 1.9 & 0.0 & 0.4 & 6.2 & 7.0 & 11.4 & 18.0 & 68.0 & 55.7 & 20.7 & 26.3 \\
\hline (k) married men & 1.1 & 0.0 & 0.1 & 2.2 & 3.5 & 5.8 & 4.6 & 12.6 & 75.5 & 70.3 & 19.9 & 17.1 \\
\hline (l) married women & 1.9 & 0.1 & 0.1 & 0.4 & 4.9 & 6.5 & 8.2 & 17.7 & 73.5 & 59.7 & 18.3 & 22.6 \\
\hline $\begin{array}{l}\text { (m) women of child- } \\
\text { bearing age (25-49) }\end{array}$ & 4.3 & 1.0 & 0.0 & 0.1 & 3.8 & 3.6 & 7.4 & 16.1 & 72.6 & 58.7 & 20.0 & 25.2 \\
\hline (n) elderly (50+) & 0.1 & 0.0 & 41.5 & 46.0 & 9.2 & 16.6 & 16.6 & 28.0 & 71.0 & 54.6 & 12.4 & 17.4 \\
\hline
\end{tabular}

Notes: The share of full-time students (1), individuals receiving an old-age pension (2) and individuals receiving a disability pension (3) and population shares by the highest level of education (4-6) as a percentage of the total 15-74 years old population (a) and as a percentage of the total number of individuals in selected subgroups $(b-n)$. 


\section{Conclusion}

Taking the example of two countries, the Czech Republic and Hungary, this paper investigates the extent to which cross-country differences in aggregate participation rates can be explained by the disparity in their tax-benefit systems. We first replicate for Czech household-level data the labour supply estimation for Hungary presented in Benczúr et al. (2014) and use the two perfectly comparable estimates of labour supply at the extensive margin to simulate how the aggregate participation rate would change in one country if it adopted the other country's tax and social welfare system.

Our estimation results yield similar labour supply elasticities for both countries, suggesting that individual preferences are essentially identical in the two countries analysed. Consistently with previous findings, lower educated individuals, the elderly and married women (or women of childbearing age) are the most responsive to tax and transfer changes.

The simulation results show that about three percentage points out of the total difference of 6.6 percentage points in the participation rates of the 15-74 years old population can be explained by differences in the tax-benefit systems. The simulated effects are quasi-symmetric for almost all subgroups, meaning that if the Czech system was adopted, the Hungarian participation rate of a specific subgroup would increase by about the same number of percentage points as the Czech participation would decrease by if the Hungarian system were implemented. The largest difference explained by the difference in the tax-benefit systems is identified for married women and women of childbearing age. This is related to the more generous maternity benefit system in place in Hungary as compared to the Czech Republic. The "unexplained" part of the difference is also likely to be affected by some elements of the transfer system that we do not explicitly control for, most importantly the differences in the old-age and disability pension schemes.

Obviously, these results cannot be directly generalised to other countries. First, it is possible that individual preferences differ more across countries with different cultural and historical backgrounds or institutional structures even within narrowly defined sub-populations. Second, cross-country differences in the composition of the working-age population may lead to different results even following a similar shock to net income levels. Nevertheless, the exercise presented in this paper sheds some light on how important the tax-benefit system can be in explaining the differences in labour force participation between two otherwise similar countries.

Finally, it is important to note that we do not suggest that Hungary should blindly adopt the Czech tax and transfer system in order to increase labour force participation. First, even though the Czech participation rate is close to the EU15 average (the usual benchmark for catching-up EU member states), the Czech system might not be optimal in every respect. Second, governments' redistributive preferences may be different and therefore the optimal policy may also differ. The Czech system is still a good benchmark for Hungary, as it provides a realistically achievable alternative for Hungarian policymakers. 


\section{References}

Aaberge, R., U. Colombino, AND S. StrøM (2000): "Labor Supply Responses and Welfare Effects from Replacing Current Tax Rules by a Flat Tax: Empirical Evidence from Italy, Norway and Sweden.” Journal of Population Economics 13(4), pp. 595-621.

BAlleer, A., R. Gómez-SAlvador, AND J. TuRunen (2009): "Labour Force Participation in the Euro Area: A Cohort Based Analysis.” Working Paper Series 1049, European Central Bank.

BARgain, O. AND A. Peichl (2013): "Steady-State Labor Supply Elasticities: A Survey." IZA Discussion Papers 7698, Institute for the Study of Labor (IZA).

Bargain, O., M. Dolls, D. Neumann, A. Peichl, And S. Siegloch (2011): "Tax-Benefit Systems in Europe and the US: Between Equity and Efficiency." IZA Discussion Papers 5440, Institute for the Study of Labor (IZA).

BARgain, O., K. OrsinI, AND A. PeICHL (2012): “Comparing Labor Supply Elasticities in Europe and the US: New Results.” IZA Discussion Papers 6735, Institute for the Study of Labor (IZA).

Benczúr, P., G. KÁtAy, AND Á. Kiss (2012): “Assessing Changes of the Hungarian Tax and Transfer System: A General-Equilibrium Microsimulation Approach.” MNB Working Papers 2012/7, Magyar Nemzeti Bank.

Benczúr, P., G. KÁtAy, Á. KISS, AND O. RÁCZ (2014): “Income Taxation, Transfers and Labour Supply at the Extensive Margin.” Working Papers 487, Banque de France.

Blundell, R., A. BoziO, AND G. LAROQUe (2011): "Extensive and Intensive Margins of Labour Supply: Working Hours in the US, UK and France." IFS Working Papers W11/01, Institute for Fiscal Studies.

Blundell, R., M. Brewer, P. HAAN, AND A. ShePhard (2009): "Optimal Income Taxation of Lone Mothers: An Empirical Comparison of the UK and Germany." Economic Journal, Royal Economic Society 119(535), pp. F101-F121.

Blundell, R. W. AND T. MACURDY (1999): "Labor Supply: A Review of Alternative Approaches." In Ashenfelter and Card (eds.), Handbook of Labor Economics, Volume 3A, Chapter 27, Elsevier North-Holland.

Blundell, R. W., T. MaCurdy, And C. MeghiR (2007): "Labor Supply Models: Unobserved Heterogeneity, Nonparticipation and Dynamics." In Heckman and Leamer (eds.), Handbook of Econometrics, Volume 6A, Chapter 69.

Bourguignon, F. AND T. MAGnAC (1990): “Labour Supply and Taxation in France.” Journal of Human Resources 25, pp. 358-389.

Chetty, R., A. Guren, D. Manoli, And A. Weber (2012): "Does Indivisible Labor Explain the Difference Between Micro and Macro Elasticities? A Meta-analysis of Extensive 
Margin Elasticities." In NBER Macroeconomics Annual 2012, Volume 27, NBER Chapters, pp. 1-51, National Bureau of Economic Research, Inc.

Cipollone, A., E. Patacchini, And G. Vallanti (2013): “Women Labor Market Participation in Europe: Novel Evidence on Trends and Shaping Factors." IZA Discussion Papers 7710, Institute for the Study of Labor (IZA).

COMMANDER, S. AND F. CORICELli (1995): "Unemployment, Restructuring, and the Labor Market in Eastern Europe and Russia.” World Bank Institute Development Studies.

Evers, M., R. DE MoOIJ, AND D. VAN VUUREN (2008): “The Wage Elasticity of Labour Supply: A Synthesis of Empirical Estimates.” De Economist 156, pp. 25-43

GALUŠČÁK, K. AND J. PAVEL (2012): "Taxes and Benefits: Work Incentive Effects of Policies." Czech Journal of Economics and Finance 62(1), pp. 27-43.

Hausman, J. A. (1981): "Labor Supply." In H. Aaron and J. Pechman (eds.), How Taxes Affect Economic Behavior, The Brookings Institution, Washington D.C., pp. 27-72.

IMF (2013): Article IV Consultation: Hungary.

Immervoll, H., H. J. Kleven, C. T. Kreiner, And E. SaEz (2007): "Welfare Reform in European Countries: A Microsimulation Analysis.” Economic Journal 117(516), pp. 144.

KÁtAy, G. AND B. NoBILIS (2009): "Driving Forces Behind Changes in the Aggregate Labour Force Participation in Hungary." MNB Working Papers 2009/5, Magyar Nemzeti Bank.

KeAne, M. P. (2011): "Labor Supply and Taxes: A Survey." Journal of Economic Literature 49(4), pp. 961-1075.

Killingsworth, M. And J. Heckman (1986): "Female Labor Supply: A Survey." In O. Ashenfelter and R. Layard (eds.), Handbook of Labor Economics, Volume 1, Amsterdam, North-Holland.

MaCurdy, T., P. GReEn AND H. PAarsch (1990): "Assessing Empirical Approaches for Analyzing Taxes and Labor Supply.” Journal of Human Resources 25, pp. 415-490.

MCFAdDEN, D. (1974): “Conditional Logit Analysis of Qualitative Choice Behavior." In P. Zarembka (ed.), Frontiers in Econometrics, New York: Academic Press, pp. 105-142.

MCFAdDEN, D. AND K. TRAIN (2000): “Mixed MNL Models for Discrete Responses.” Journal of Applied Econometrics 15(5), pp. 447-470.

MeghiR, C. AND D. Phillips (2008): "Labour Supply and Taxes." The Mirrlees Review: Reforming the Tax System for the 21st Century.

OECD (2012): Economic Survey Hungary 2012.

OECD (2014): Economic Survey Czech Republic 2014. 
PAulus, A. AND A. PEICHL (2008): "Effects of Flat Tax Reforms in Western Europe on Income Distribution and Work Incentives." IZA Discussion Papers 3721, Institute for the Study of Labor (IZA).

PencAVel, J. (1986): “Labor Supply of Men: A Survey.” In O. Ashenfelter and R. Layard (eds.), Handbook of Labor Economics, Volume 1, Amsterdam, North-Holland.

VAN SoEST, A. (1995): "Structural Models of Family Labor Supply: A Discrete Choice Approach." Journal of Human Resources 30, pp. 63-88.

VAn Soest, A. AND M. DAS (2001): "Family Labor Supply and Proposed Tax Reforms in the Netherlands." De Economist 149(2), pp. 191-218. 


\section{Appendix A: Description of the Welfare Benefit Systems}

\section{A.1 Hungary}

Maternity benefit is paid to insured women who are away from work as a result of pregnancy. In Hungary, it is an insurance-based benefit, conditional on past employment. It is divided into three or four parts. The first part ("Maternity benefit"), equal to $70 \%$ of the past monthly wage, is received by mothers for 5 months around childbirth. The second part ("Child-care benefit I") is another insurance-based benefit of the same amount that one of the parents collects until the second birthday of the youngest child. The third part ("Child-care benefit II") is not conditional on employment or insurance history. One of the parents is eligible for the benefit until the third birthday of the youngest child. The fourth part ("Child-care benefit III") is available to a parent if he or she raises three children until the eighth birthday of the youngest child, independently of employment or insurance history. These benefits are mutually exclusive and recipients are restricted from working full time.

Unemployment benefits (UB) are also insurance-based benefits. Depending on unemployment spell and eligibility, two types of benefits exist: UB I has a maximum duration of 9 months, split into two phases. In 2008, the recipient received $60 \%$ of the previous wage during the first half of the period (not longer than 3 months) and $60 \%$ of the minimum wage during the remaining phase; UB II is a fixed-sum benefit for individuals whose UB I expired without finding a job or for those who are not eligible for UB I. It is conditional on cooperation with the local unemployment administration. The benefit is equal to $40 \%$ of the minimum wage. Individuals who lose their job in the period of 5 years prior to the statutory pension age are entitled to pre-retirement unemployment benefit. This insurance-based benefit is equal to $40 \%$ of the minimum wage and is suspended if the individual finds a job.

Family allowance is a universal benefit for families with children. The amount of the benefit depends on the number of children. The benefit is not conditional on work.

Regular social benefit is a welfare benefit that an individual may receive if he or she is not eligible for any other unemployment, disability or child-care benefits. After 2006 the benefit supplemented the family income to $90 \%$ of the minimum pension benefit per consumption unit, but the total could not exceed the net minimum wage.

\section{A.2 Czech Republic}

In the Czech Republic, the social security system consists of social insurance benefits, state social support and social assistance. Benefit is not subject to income taxation.

The social insurance benefits consist of unemployment, sickness and pension insurance benefits. Maternity benefit is part of the sickness contribution provided to mothers until 6 months after childbirth. The amount of the benefit is equal to $69 \%$ of the previous gross income.

Unemployed persons may receive unemployment benefits for a maximum period of 6 months. The amount of the benefit is 50\% of the net previous work income in the first 3 months and $45 \%$ in the following months of the support period, while a maximum amount is applied. The support period is longer for older job seekers. 
The state social support is targeted mainly at families with children and is based on the concept of the living minimum as stipulated by legislation. The income of the whole family is tested for the purposes of the child allowance (family benefit, "pridavek na dite"), the social allowance ("socialni priplatek") and the housing allowance ("priplatek na bydleni"). Income is not examined for the parental allowance, the foster care benefit, the birth grant and the funeral grant. The parental allowance is usually provided to mothers caring daily for a child until the age of 2 , 3 or 4 , but gainful activity is allowed.

Social assistance (assistance in material need) is the last resort for persons or families who are not able to afford the minimum living requirements as recognised by the state in the so-called living minimum (i.e. those in material need). The amounts of the living minimum are different for single persons, for first and other adult household members and for children. Social assistance gives preferential treatment to those recipients of benefits in material need who are actively seeking work or are working. For persons who are not eligible for material need assistance, the subsistence minimum is defined to cover personal needs on a survival level. Housing needs are covered separately by the housing allowance in state social support and by a housing supplement, which is a part of social assistance. 


\section{Appendix B: Comparison of Czech and Hungarian Income Variables}

\section{Table B1: Hungarian - Czech Correspondence Table}

\begin{tabular}{|c|c|c|c|c|}
\hline & Variable name & $\begin{array}{c}\text { Gross or net? If gross, normal or } \\
\text { separate taxation? }\end{array}$ & $\begin{array}{c}\text { Individual (i) } \\
\text { or household } \\
\text { level (hh) } \\
\text { variable? }\end{array}$ & Corresponding $\mathrm{CZ}$ variable \\
\hline \multicolumn{5}{|l|}{ INCOME FROM WORK } \\
\hline wage income from main employment & esmbe & nomal taxation & $\mathrm{i}$ & hp_hzam \\
\hline wage income from secondary employment & esmas & nomal taxation & $\mathrm{i}$ & hp_vzam \\
\hline income from intellectual property & essze & $0.9 \mathrm{x}$ normal taxation & $\mathrm{i}$ & 0 \\
\hline income from ad hoc engagement agreement & esmegb & $0.9 \times$ normal taxation & $\mathrm{i}$ & 0 \\
\hline income from entrepreneurial activity, individual & eseva & nomal taxation & $\mathrm{i}$ & hp_podn+hp_vcin \\
\hline income from entrepreneurial activity, joint business & esarval & nomal taxation & $\mathrm{i}$ & 0 \\
\hline entrepreneurial income, explicitly after taxes & esevarbe 25 & net & $\mathrm{i}$ & 0 \\
\hline income from agricultural activities & mezj & net & hh & hh_p_prodej \\
\hline income from agricultural activities (income - costs) & emezertek - emezraf & normal tax. if emerzetek > 600000 & hh & 0 \\
\hline own occasional production at home & ehstaj & net & $\mathrm{i}$ & 0 \\
\hline occasional work & esalk & net & $\mathrm{i}$ & 0 \\
\hline tips & esbor & net & $\mathrm{i}$ & 0 \\
\hline restoration allowance & esket & net & $\mathrm{i}$ & 0 \\
\hline recreation allowance & eskud & net & $\mathrm{i}$ & 0 \\
\hline housing subsidy & eskal & net & $\mathrm{i}$ & 0 \\
\hline clothing allowance & eskru & net & $\mathrm{i}$ & 0 \\
\hline travel reimbursement & eskge & net & $\mathrm{i}$ & 0 \\
\hline schooling allowance (for children) & eskis & net & $\mathrm{i}$ & 0 \\
\hline company car for private use & escma & net & $\mathrm{i}$ & 0 \\
\hline internet allowance & espci & net & $\mathrm{i}$ & 0 \\
\hline cell phone for private use & esmobm & net & $\mathrm{i}$ & 0 \\
\hline other & eskeg & net & $\mathrm{i}$ & 0 \\
\hline sickness allowance & estapft $^{(1)}$ & nomal taxation & $\mathrm{i}$ & part of hh_nemoc ${ }^{(2)}$ \\
\hline \multicolumn{5}{|l|}{ NON-LABOUR INCOME ${ }^{(3)}$} \\
\hline old age pension & esnyusa & net, but part of the tax base & $\mathrm{i}$ & duch if dduch $==1^{(4)}$ \\
\hline complement old-age pension for widow(er) & esonyuki & net, but part of the tax base & $\mathrm{i}$ & duch if dduch $==2$ \\
\hline pension for orphan(s) & earvft & net & hh & duch if dduch $==5$ \\
\hline widow's pension & esozvegy & net, but part of the tax base & $\mathrm{i}$ & duch if dduch $==6$ \\
\hline one-time maternity aid & esanys & net & $\mathrm{i}$ & 0 \\
\hline travel aid for persons with reduced mobility & esmkta & net & $\mathrm{i}$ & 0 \\
\hline foster care benefit & ecspiki & net & hh & hh_pestp+hh_rodp \\
\hline housing allowance & elfe & net & hh & hh_pbydl ${ }^{(5)}$ \\
\hline other social supports & esjar & net & $\mathrm{i}$ & hh_ost_dav+hh_jine_socp \\
\hline income from pension and life insurance & ebiz & net & hh & hh_p_jinpoj+hh_p_zivpoj+hh_d_penz \\
\hline dividend (capital income) & efelkoa & net & hh & hh_p_majet \\
\hline dividend from own business & esvalos & separate taxation & $\mathrm{i}$ & 0 \\
\hline income from house/other rent & esiha & separate taxation & $\mathrm{i}$ & 1/0.75 x hh_p_pronaj ${ }^{(6)}$ \\
\hline income from abroad & eskujm & net & $\mathrm{i}$ & 0 \\
\hline income from abroad (other) & eskuje & net & $\mathrm{i}$ & 0 \\
\hline income of minors & ejovgy ft & net & hh & 0 \\
\hline child support & cgyta & net & hh & 0 \\
\hline life annuity pay ments & eskje & net & $\mathrm{i}$ & 0 \\
\hline other non-labour income & eejo & net & hh & hh_jine_ostp \\
\hline other non-labour income in kind & termj & net & hh & 0 \\
\hline scholar grants ${ }^{(7)}$ & esosz & net, but part of the tax base & $\mathrm{i}$ & 0 \\
\hline severance indemnities $^{(7)}$ & esveg & & $\mathrm{i}$ & 0 \\
\hline \multicolumn{5}{|l|}{ TRANSFERS $^{(8)}$} \\
\hline disability pension & esny uro & net, but part of the tax base & $\mathrm{i}$ & duch if dduch $==3$ or dduch $==4$ \\
\hline \multicolumn{5}{|c|}{$\begin{array}{l}\text { Notes: (1) the survey explicitly asks whether the income reported from sick leave is to be meant in net or gross terms. An indicator variable, esbesza = } 1 \text { if estapft has } \\
\text { already been taken into account in other income variable; (2) hh_nemoc combines maternity benefit and sickness allowance. It has been recoded as maternity benefit if the } \\
\text { household is eligible for it according to the legislation in force. If the household does not meet the eligibility criteria for maternity benefit, hh_nemoc is considered to be } \\
\text { sickness allowance and is split among adult working members of the household; (3) the non-labour income enters the equation at the household level. Accordingly, all } \\
\text { variables were aggregated at the household level; (4) dduch is an indicator variable associated with the variable duch; (5) means-tested in CZ; (6) hh_p_pronaj is } \\
\text { recorded in net terms, we transformed into gross revenue; (7) set to zero for the simulation; (8) the other transfer elements were generated according the eligibility } \\
\text { criteria }\end{array}$} \\
\hline
\end{tabular}


Table B2: Czech - Hungarian Correspondence Table

\begin{tabular}{|c|c|c|c|c|}
\hline & Variable name & $\begin{array}{c}\text { Gross or net? If gross, normal or } \\
\text { separate taxation? }\end{array}$ & $\begin{array}{c}\text { Individual (i) } \\
\text { or household } \\
\text { level (hh) } \\
\text { variable? }\end{array}$ & Corresponding HU variable \\
\hline \multicolumn{5}{|l|}{ INCOME FROM WORK } \\
\hline wage income from main employment & hp_hzam & nomal taxation & $\mathrm{i}$ & esmbe \\
\hline wage income from secondary employment & hp_vzam & nomal taxation & $\mathrm{i}$ & esmas+essze+esmegb \\
\hline income from main entrepreneurial activity & hp_podn & nomal taxation & $\mathrm{i}$ & eseva+esarval $+1 / 0.75 \times$ esevarbe 25 \\
\hline income from secondary entrepreneurial activity & hp_vcin & nomal taxation & $\mathrm{i}$ & 0 \\
\hline own occasional production at home & hh_p_prodej & net & hh & $\begin{array}{l}\text { mezj + (emezertek - emezraf })+ \text { ehstaj } \\
(1) \\
+ \text { esbor }^{(1)}+\text { esket }^{(1)}+\text { eskud }^{(1)}+\text { eskal }^{(1)} \\
+ \text { eskru }^{(1)}+\text { eskge }^{(1)}+\text { eskis }^{(1)}+\text { escma }^{(1)} \\
\quad+\text { espci }^{(1)}+\text { esmobm }^{(1)}+\text { eskeg }^{(1)}\end{array}$ \\
\hline sickness allowance & part of hh_nemoc ${ }^{(2)}$ & net & hh & estapft $^{(1),(3)}$ \\
\hline \multicolumn{5}{|l|}{ NON-LABOUR INCOME ${ }^{(4)}$} \\
\hline old age pension & duch if dduch $==1^{(5)}$ & net & $\mathrm{i}$ & esnyusa \\
\hline complement old-age pension for widow(er) & duch if dduch==2 & net & $\mathrm{i}$ & esonyuki \\
\hline pension for orphan(s) & duch if dduch $==5$ & net & $\mathrm{i}$ & earvft \\
\hline widow's pension & duch if dduch $==6$ & net & $\mathrm{i}$ & esozvegy \\
\hline other pensions & duch if dduch $==7$ & net & $\mathrm{i}$ & esanys+esmkta \\
\hline foster care benefit & hh_pestp & net & hh & ecspiki \\
\hline parental allowance & hh_rodp & net & hh & 0 \\
\hline housing allowance & hh_pbydl ${ }^{(6)}$ & net & hh & elfe \\
\hline other social supports & hh_ost_dav & net & hh & esjar \\
\hline other social supports II & hh_jine_socp & net & hh & 0 \\
\hline income from pension and life insurance & hh_p_jinpoj & net & hh & ebiz \\
\hline income from other insurance & hh_p_zivpoj & net & hh & 0 \\
\hline pension from voluntary pension insurance & hh_d_penz & net & hh & 0 \\
\hline dividend (capital income) & hh_p_majet & net & hh & efelkoa +0.75 x esvalos $^{(7)}$ \\
\hline income from house/other rent & hh_p_pronaj & net & hh & $0.75 \times$ esiha $^{(7)}$ \\
\hline other non-labour income & hh_jine_ostp & net & hh & $\begin{array}{c}\text { eskujm }+ \text { eskuje }+ \text { ejovgyft }+ \text { cgyta }+ \\
\text { eskje }+ \text { eejo }+ \text { termj }\end{array}$ \\
\hline \multicolumn{5}{|l|}{ TRANSFERS $^{(8)}$} \\
\hline disability pension & $\begin{array}{c}\text { duch if dduch }==3 \\
\text { or dduch }==4\end{array}$ & net, but part of the tax base & $\mathrm{i}$ & esny uro \\
\hline
\end{tabular}

Notes: (1) aggregated to the household level; (2) hh_nemoc combines maternity benefit and sickness allowance. It has been recoded as maternity benefit if the household is eligible for it according to the legislation in force. If the household does not meet the eligibility criteria for maternity benefit, hh_nemoc is considered to be sickness allowance and is split among adult working members of the household; (3) the survey explicitly asks whether the income reported from sick leave is to be meant in net or gross terms. An indicator variable, esbesza $=1$ if estapft has already been taken into account in other income variable; (4) the non-labour income enters the equation at the household level. Accordingly, all variables were aggregated at the household level; (5) dduch is an indicator variable associated with the variable duch; (6) meanstested in CZ; (7) esvalos and esiha are recorded in gross terms, we transformed them into net revenues; (8) the other transfer elements were generated according the eligibility criteria 